\title{
Scheduling Optimization of Swakelola Projects in The Irrigation Water Utilization Improvement Program (P3-TGAI)
}

\author{
Musa Mardwiana Thohir ${ }^{1}$, Anak Agung Bagus Dinariyana Dwi Putranta ${ }^{2}$, and Adithya Sudiarno ${ }^{3}$ \\ ${ }^{1,2}$ Department of Technology Management, Institut Teknologi Sepuluh Nopember, Surabaya \\ ${ }^{3}$ Department of Industrial and Systems Engineering, Institut Teknologi Sepuluh Nopember, Surabaya \\ e-mail: musamardwiana@gmail.com
}

\begin{abstract}
The Irrigation Water Utilization Improvement Program (P3-TGAI) is a program implemented by the Balai Besar Wilayah Sungai Brantas (BBWS) which aims to improve irrigation networks by building tertiary/small canals. Kediri, Trenggalek, Tulungagung, Blitar are one of the regional packages that received the program. In the implementation of P3-TGAI in the area, there were problems with the completion of the program. Monitoring and controlling program are needed to ensure the implementation timeliness. Critical Path Method (CPM) analysis is a method used to estimate the minimum duration of a project by connecting each activity and determine the duration of each activity. This method is carried out through the stages of collecting secondary and primary data to identify internal and external factors that affect the speed of the program. Project management analysis method is used to approach the monitoring and controlling program so that it is timely. The expected result from CPM analysis is to get an optimal program design schedule for the implementation of P3TGAI.
\end{abstract}

Keywords-CPM Analysis, P3-TGAI, Project Time Management.

\section{INTRODUCTION}

$\mathrm{P}$ ROCUREMENT of goods / services The government has an important role in the implementation of national development to improve public services and develop the national and regional economies. According to Presidential Regulation, procurement of government goods / services can be carried out in 2 ways, namely through goods / service providers and through swakelola. Procurement of goods / services through swakelola is a way of obtaining goods / services which is done by the Ministry / Institution / Regional Apparatus / Community Group.

The Program for the Acceleration of Improving Irrigation Water Use (P3-TGAI) is an annual program implemented by the Balai Besar Wilayah Sungai (BBWS) Brantas which is self-managed by the Water User Farmer Association (P3A). This activity, which has been implemented since 2013, is aimed at improving irrigation networks by building tertiary / small channels. Besides, P3-TGAI also aims to increase community participation in channel development. So that this program is also useful for increasing employment in villages that receive assistance.

Constraints in construction projects are always found in every implementation, including in the implementation of P3TGAI activities. The problem that often occurs is the delay in disbursing project funds because the administrative process for disbursement is often constrained. The program duration is planned according to the stated schedule, which is 5 months, however, in its implementation there is always a delay in the completion of the final report up to 8 to 9 months. This delay resulted in losses to the self-managed implementer as the beneficiary and also to the supervisor who only received a 5-month contract but had to work for 8 months. The government, represented by the Commitment Making Officer (PPK), is also a problem regarding the performance appraisal of these officials. So that reporting to the central level in this case to the Ministry of Public Works in the Water Resources Sector also cannot be on time according to the specified budget year. This problem occurred in the implementation of P3-TGAI in package 1 areas (Trenggalek Regency, Kediri City, Tulungagung Regency and Blitar Regency).

From the description of the problems that have been previously described, it is known that there is still no good management, especially regarding scheduling. According to Rosanti, N., Setiawan, E. and Ayuningtyas, . A. (2016) the use of the critical path method can provide information to prevent delays, information about tolerance for delays, and remind team members about activities whose due date / deadline is near [6]. Determination of the critical network is useful for determining where project activities should be accelerated [7]. In this study, the Critical Path Method (CPM) was used to obtain the optimal program schedule design for the implementation of P3-TGAI.

\section{LITERATURE REVIEW}

\section{A. Project Time Management}

In Project Management Institute, Inc (2013) Project time management includes the processes required to manage project completion in a timely manner. The time management process is divided into 7 stages, namely:

1. Plan Schedule Management.

2. Define Activities.

3. Sequence Activities.

4. Estimate Activity Resources.

5. Estimate Activity Duration.

6. Develop Schedule.

7. Control Schedule [1]. 
The $6^{\text {th }}$ International Seminar on Science and Technology (ISST) 2020

July $25^{\text {th }}, 2020$, Institut Teknologi Sepuluh Nopember, Surabaya, Indonesia

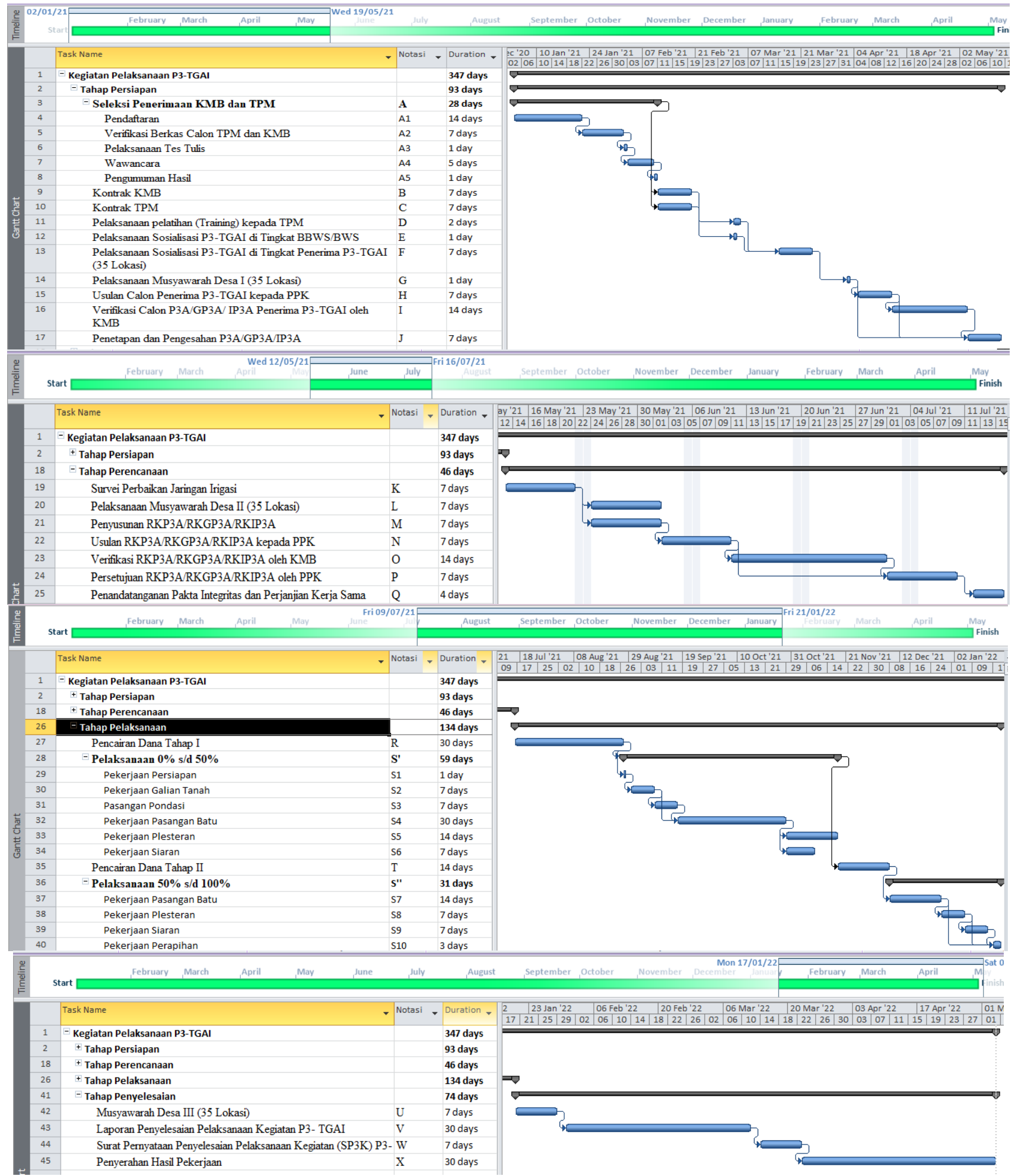

Figure 1. The Results of Sequencing Activities.

\section{1) Plan Schedule Management}

Plan Schedule Management is the process of establishing the policies, procedures, and documentation for planning, developing, managing, executing, and controlling the project schedule. The key benefit of this process is that it provides guidance and direction on how the project schedule will be managed throughout the project.

\section{2) Define Activities}

Define Activities is the process of identifying and documenting the specific actions to be performed to produce the project deliverables. The key benefit of this process is to break down work packages into activities that provide a basis for estimating, scheduling, executing, monitoring, and controlling the project work. 


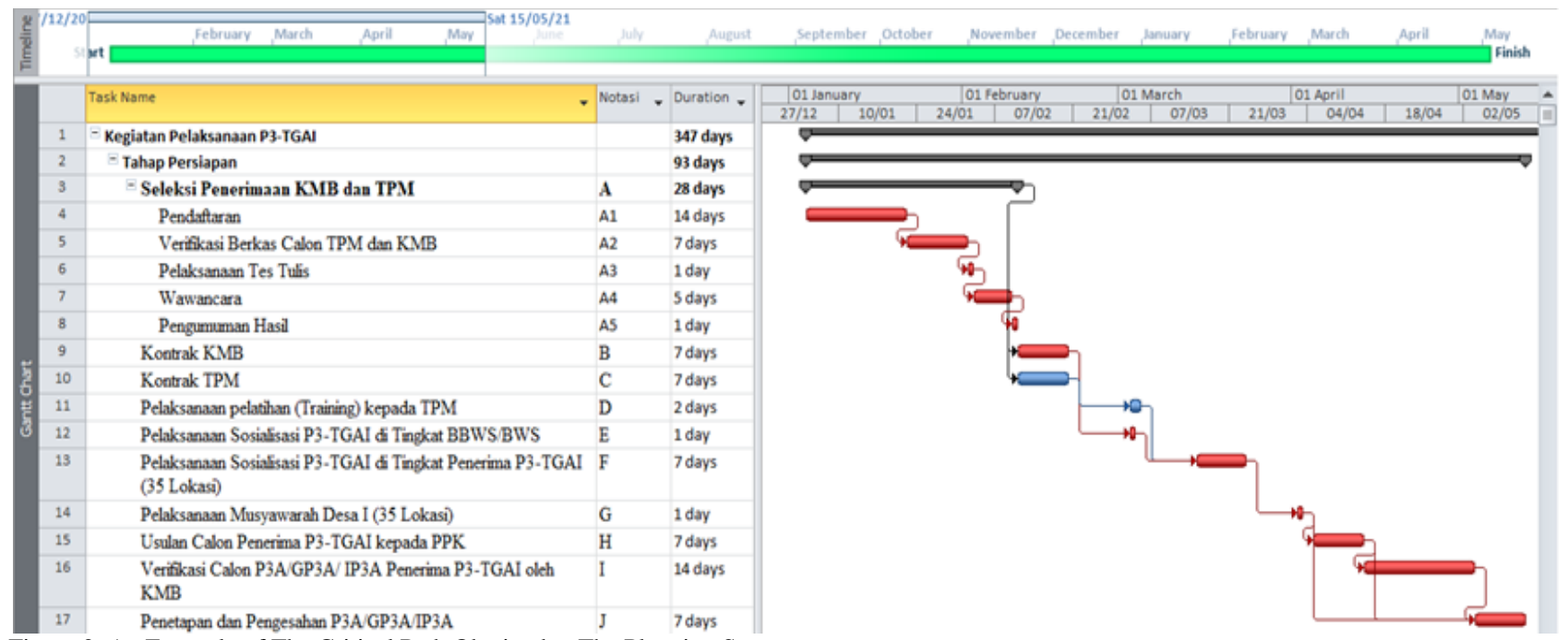

Figure 2. An Example of The Critical Path Obtained at The Planning Stage.

\section{3) Sequence Activities}

Sequence Activities is the process of identifying and documenting relationships among the project activities. The key benefit of this process is that it defines the logical sequence of work to obtain the greatest efficiency given all project constraints.

\section{4) Estimate Activity Resources}

Estimate Activity Resources is the process of estimating the type and quantities of material, human resources, equipment, or supplies required to perform each activity. The key benefit of this process is that it identifies the type, quantity, and characteristics of resources required to complete the activity which allows more accurate cost and duration estimates.

\section{5) Estimate Activity Durations}

Estimate Activity Durations is the process of estimating the number of work periods needed to complete individual activities with estimated resources. The key benefit of this process is that it provides the amount of time each activity will take to complete, which is a major input into the Develop Schedule process.

\section{6) Develop Schedule}

Develop Schedule is the process of analyzing activity sequences, durations, resource requirements, and schedule constraints to create the project schedule model. The key benefit of this process is that by entering schedule activities, durations, resources, resource availabilities, and logical relationships into the scheduling tool, it generates a schedule model with planned dates for completing project activities.

\section{7) Control Schedule}

Control Schedule is the process of monitoring the status of project activities to update project progress and manage changes to the schedule baseline to achieve the plan. The key benefit of this process is that it provides the means to recognize deviation from the plan and take corrective and preventive actions and thus minimize risk.

\section{B. CPM Analysis}

According to Project Management Institute, Inc (2013)
CPM is a method used to estimate the minimum project duration and determine the amount of scheduling flexibility on a logical network path in a schedule model. This schedule analysis technique calculates the Early Start (ES), Early Finish (EF), Late Start (LS), and Late Finish (LF) dates and is entered into the activity node. Activity Node is an activity that must be done and requires a certain time [1].

The following is an understanding of the terms in the Activity Node:

- Early Start (ES) = the earliest start time of an activity

- Early Finish $(\mathrm{EF})=$ the earliest time to finish an activity

- Late Start (LS) = the last time the activity can be started

- Late Finish $(\mathrm{LF})=$ the last time the activity can be finished

- Duration $=$ time needed to complete activities

- $\quad$ Total Float = time difference between LS and EF

\section{Previous Research}

Firmansyah, A. and Aryanny , E (2020) has conducted a study on the scheduling of a ship hull building project at PT $\mathrm{XYZ}$ using the CPM method. PT. XYZ is required to be able to carry out production on time and delays in the processing process can hinder production performance and increase working time. The research that has been done aims to schedule the building of ships, especially the hull. The first step is to collect from the company to get a job description that is needed in the manufacture of the hull. Then do forward and backward calculations to get a network diagram and the critical path of the job can be found. After that, the work acceleration calculation (Crash Program) is carried out for each activity on the critical path and the additional costs due to the acceleration are calculated. From the acceleration, the optimal time will be sought from the minimum total project cost. So the results obtained from the acceleration of 101 days to 80 days with a decrease in costs of $1.16 \%$ from the previous [2].

Nalhadi, A. and Suntana, N (2017) conducted a study on optimizing the work of a project carried out by a contractor company using the CPM method in their journal "SukaciBaros Village Infrastructure Analysis with the Critical Path Method (CPM)". The object of this research is the agropolitan area infrastructure development project (Rigit Payement) in 
Table 1.

List of Activities from P3-TGAI.

\begin{tabular}{|c|c|c|}
\hline No & Task & Authority \\
\hline 1 & Pembentukan TTP & Kementrian PUPR \\
\hline 2 & Penyususnan Petunjuk Teknis P3-TGAI & Kementrian PUPR \\
\hline 3 & Pembentukan TPB & Kementrian PUPR \\
\hline 4 & Pengadaan Konsultasn Tingkat Pusat dan BBWS/BWS & Kementrian PUPR dan BBWS \\
\hline 5 & Penjaringan Usulan Lokasi P3-TGAI & Kementrian PUPR dan BBWS \\
\hline 6 & Validasi Lokasi D.I. Oleh TPB & Kementrian PUPR dan BBWS \\
\hline 7 & Validasi Lokasi D.I.P3-TGAI dari Kepala BBWS/BWS ke Menteri & Kementrian PUPR dan BBWS \\
\hline 8 & Seleksi Penerimaan KMB dan TPM & BBWS \\
\hline 9 & SK Penetapan Lokasi D.I. P3-TGAI & Kementrian PUPR dan BBWS \\
\hline 10 & Sosialisasi Kegiatan P3-TGAI di Tingkat Pusat & Kementrian PUPR dan BBWS \\
\hline 11 & Kontrak KMB & BBWS \\
\hline 12 & Pelakasanaan ToT kepada TPB dan/atau KMB & Kementrian PUPR dan BBWS \\
\hline 13 & Kontrak TPM & BBWS \\
\hline 14 & Pelakasanaan Pelatihan (Training) kepada TPM & BBWS \\
\hline 15 & Pelaksanaan Sosialisasi P3-TGAI di Tingkat BBWS/BWS & BBWS \\
\hline 16 & Pelakasanaan Sosialisasi P3-TGAI di Tingkat Penerima P3-TGAI & BBWS \\
\hline 17 & Pelaksanaan Musyawarah Desa I & BBWS \\
\hline 18 & Usulan Calon Penerima P3-TGAI & BBWS \\
\hline 19 & Verifikasi Calon P3A/GP3A/ IP3 A Penerima P3-TGAI oleh KMB & BBWS \\
\hline 20 & Penetapan dan Pengesahan P3A/ GP3A/IP3A & BBWS \\
\hline 21 & Survei Perbaikan Jaringan Irigasi & BBWS \\
\hline 22 & Pelakasanaan Musyawarah Desa II & BBWS \\
\hline 23 & Penyusunan RKP3A/RKGP3A/RKIP3A & BBWS \\
\hline 24 & Usulan RKP3A/RKGP3A/RKIP3A kepada PPK & BBWS \\
\hline 25 & Verifikasi RKP3A/RKGP3A/RKIP3A oleh KMB & BBWS \\
\hline 26 & Persetujuaan RKP3A/RKGP3A/RKIP3A oleh PPK & BBWS \\
\hline 27 & Penandatanganan Pakta Integritas dan Perjanjian Kerja Sama & BBWS \\
\hline 28 & Pencairan Dana Tahap I & BBWS \\
\hline 29 & Pelaksanaan, Pemantauan, Pengawasan dan Evaluasi & BBWS \\
\hline 30 & Pencairan Dana Tahap II & BBWS \\
\hline 31 & Musyawarah Desa II & BBWS \\
\hline 32 & Laporan Penyelesaian Pelaksanaan Kegiatan P3-TGAI & BBWS \\
\hline 33 & Surat Penyelesaian Pelaksanaan Kegiatan (SP3K) P3-TGAI & BBWS \\
\hline 34 & Penyerahan Hasil Pekerjaan & BBWS \\
\hline
\end{tabular}

Sukaci - Baros Village. The project experienced a delay of 19 days from the specified time, which was 126 days, so that it experienced cost overruns, because poor company management was the root of the problem. The required data collection is in the form of theoretical data collection and historical data. Theoretical data are in the form of theories on project management, EET (Earliest Event Time) calculation, LET (Latest Event Time) calculation, and delay (Float). The historical data required is variable data, namely quantitative data on the Gantt Chart, Network diagram and Schedule. The time emphasis that will be done is to accelerate the project duration with the alternative of additional working hours and additional employees to be taken whichever costs the least possible alternative. One of the ways to speed up the project duration is called crashing in foreign terms. For this reason, project optimization is carried out in 2 ways, namely the addition of overtime hours on Monday-Wednesday with a duration of 2 hours each and additional employees. From this method, two alternative crashes were obtained, namely an acceleration of the project duration. So the decision was made to use the addition of overtime hours because the costs incurred were less. The additional work time was able to save on project work from 126 days to 92 days with a profit compared to work on the original plan [4].

Priyanto, E., Ervadius, B. and Mochamad Anang, W (2019) conducted a study of the time and cost acceleration of a steam turbine fabrication project using the CPM method in their journal "Acceleration of Time and Costs for the Planning of Muara Tawar Block 2 Steam Turbine Building
Fabrication Project with the CPM Method". The purpose of this study, among others, is to find out the work network or network, optimal time, and the cost of the Building Block 2 Steam Turbine Fabrication project.In this study the data required is data regarding activity time, project implementation schedule, project costs, and estimated needs data. project workforce. From this data, a Work Breakdown Structure (WBS) is obtained. The use of the WBS can help the process of controlling and scheduling a project, so that the WBS can be used to divide work elements, describe the project in a level structure format, cover all work to completion. After that, processing with CPM is by making a network diagram that presents activities, activity names, predecessors, workers and implementation time. Through the network diagram, it can be seen which work paths are included in the critical path. After it is known that the critical path in the project is accelerated and the impact of the cost of the acceleration itself or the cost slope is calculated. The result of the analysis carried out is that the initial project duration is 148 days according to the calculation using the CPM method [5].

Herianto, Mahdi, I. and Asif, M (2020) planned a project schedule by applying the PERT (Program Evaluation and Review Technique) and Crashing method in the BKPSDM BKPSDM DIKLAT Facility Building project, Ciamis district. The problem that often occurs in each project implementation is the delay in the completion of the project which ultimately causes an increase in expenditure costs that exceed the budgeted funds. The objectives of this research 
Table 2.

The List of Activities on The Process Stages of The P3-TGAI

\begin{tabular}{|c|c|c|}
\hline \multicolumn{3}{|c|}{ Preparation Stage } \\
\hline 1 & Seleksi Penerimaan KMB dan TPM & A \\
\hline 2 & Kontrak KMB & B \\
\hline 3 & Kontrak TPM & $\mathrm{C}$ \\
\hline 4 & Pelaksanaan Pelatihan (Training) kepada TPM & $\mathrm{D}$ \\
\hline 5 & Pelaksanaan Sosialisasi P3-TGAI di Tingkat BBWS/BWS & E \\
\hline 6 & Pelaksanaan Sosialisasi P3-TGAI di Tingkat Penerima P3-TGAI & $\mathrm{F}$ \\
\hline 7 & Pelaksanaan Musyawarah Desa I & G \\
\hline 8 & Usulan Calon Penerima P3-TGAI kepada PPK & $\mathrm{H}$ \\
\hline 9 & Verifikasi Calon P3A/GP3A/IP3A Penerima P3-TGAI oleh KMB & I \\
\hline 10 & Penetapan dan Pengesahan P3A/ & $\mathrm{J}$ \\
\hline \multicolumn{3}{|c|}{ Planning Stage } \\
\hline No & Task & ID \\
\hline 1 & Survei Perbaikan Jaringan Irigasi & $\mathrm{K}$ \\
\hline 2 & Pelaksanaan Musyawarah Desa II & $\mathrm{L}$ \\
\hline 3 & Penyusunan RKP3A/RKGP3A/RKIP3A & M \\
\hline 4 & Usulan RKP3A/RKGP3A/RKIP3A kepada PPK & $\mathrm{N}$ \\
\hline 5 & Verifikasi RKP3A/RKGP3A/RKIP3A oleh KMB & $\mathrm{O}$ \\
\hline 6 & Persetujuan RKP3A/RKGP3A/RKIP3A oleh PPK & $\mathrm{P}$ \\
\hline 7 & Penandatanganan Pakta Integritas dan Perjanjian Kerja Sama & Q \\
\hline \multicolumn{3}{|c|}{ Implementation Stage } \\
\hline No & ID & ID \\
\hline 1 & Pencairan Dana Tahap I & $\mathrm{R}$ \\
\hline 2 & Pelaksanaan, Pemantauan, Pengawasan dan Evaluasi & $\mathrm{S}$ \\
\hline 3 & Pencairan Dana Tahap II & $\mathrm{T}$ \\
\hline \multicolumn{3}{|c|}{ Completion Stage } \\
\hline No & ID & ID \\
\hline 1 & Musyawarah Desa II & $\mathrm{U}$ \\
\hline 2 & Laporan Penyelesaian Pelaksanaan Kegiatan P3-TGAI & $\mathrm{V}$ \\
\hline 3 & Surat Pernyataan Penyelesaian Pelaksanaan Kegiatan (SP3K)P3-TGAI & W \\
\hline 4 & Penyerahan Hasil Pekerjaan & $\mathrm{X}$ \\
\hline
\end{tabular}

are, among others, to obtain the fastest completion time by considering the estimated time for completion of the project due to the uncertainty that occurs in the field, in order to obtain a percentage of the probability of completion of the project using the PERT analysis. As well as estimating how much it will cost if the project completion time is accelerated. Basically the calculation of the critical path in the PERT method is similar to other methods such as CPM or PDM, where the total project duration is calculated by adding up the duration of the work that is on the critical path, but in the PERT method there are three time estimates that need to be considered in determining the expected optimal duration. of every job [3].

\section{METHODOLOGY}

The object of this research is the P3-TGAI for the 2019 fiscal year carried out by BBWS Brantas. In its implementation, problems occur, especially related to time that is not according to plan.

Data collection is divided into 2, namely primary data and secondary data. Primary data was obtained from interviews, discussions and FGD (Forum Group Discussion) with related parties at P3-TGAI. Starting from community groups as implementers of self-government to BBWS as organizers of P3-TGAI. For secondary data obtained from the 2019 P3TGAI Balai Management Consultant annual report in package 1 areas as well as implementation reports by the implementing group in the field.

From the data obtained, activity identification was carried out using 7 processes of project time management, namely:

1. Plan Schedule Management.
2. Define Activities.
3. Sequence Activities.
4. Estimate Activity Resources.
5. Estimate Activity Duration.
6. Develop Schedule.
7. Control Schedule.

After analyzing the activities, the next stage is to calculate the Forward Pass and Backward Pass. This is to find out the critical trajectory of the series of activities at P3-TGAI. Then solution formulation is carried out by making alternative schedules based on a predetermined critical path.

From the alternative schedule made analysis and discussion to ensure that the schedule made is relevant to P3TGAI. Draw conclusions on the analysis carried out on the optimization of the planned schedule. It is hoped that the schedule made can be applied to the P3-TGAI project in the following year.

\section{RESULT AND DISCUSSION}

By collecting secondary data and tertiary data from interviews with parties related to P3-TGAI, several important points were obtained in the delay in implementing the P3TGAI, namely:(1)The ministerial decree decree on the determination of the P3-TGAI location was late, so field supervisors could not yet go into the field; (2)Administrative requirements for villages that receive a P3-TGAI are still incomplete, especially regarding the legality of the $\mathrm{P} 3 \mathrm{~A}$ management and the account book in the name of the P3A; (3)The distance for the disbursement of Phase 1 funds was too long starting from the signing of the Cooperation Agreement (PKS) between PPK and the Chairperson of the 
P3A. In the PKS there is a period of work that must be completed by the P3A for 110 calendar days.

By processing secondary data from P3-TGAI and primary data from discussions and interviews with parties involved in P3-TGAI. Obtained all existing activities in the implementation of P3-TGAI. The list of activities obtained are then grouped based on the authority for these activities. The authority referred to here is the party authorized or responsible for an activity. Authority grouping is divided into two, namely the authority of the PUPR ministry and the authority of BBWS Brantas. The list of activities and authorities can be seen in Table 1 and it is known that the total activities are 34 activities and the BBWS authorities are 24 activities. The list of activities discussed in this study are those under the authority of BBWS Brantas.

From this process the entire list of P3-TGAI activities is grouped into several parts to make it easier to manage. The grouping of activities is carried out based on the process stages of the P3-TGAI. Therefore the list of activities is grouped into 4 parts, namely:

1. Preparation Stage

2. Planning Stage

3. Implementation Stage

4. Completion Stage

In this process, coding is also carried out for each activity as showed in Table 2. With this code, it will be easier to analyze activities in the next process.

After that, the activity sequencing was carried out from the 4 stages of P3-TGAI. The sequencing of these activities is carried out using the Presedence Diagramming Method (PDM) method. The results of sequencing activities can be seen in Error! Reference source not found.. After the sequence of activities has been formed, enter into the resource estimation process and estimate the duration of time required to carry out each activity at P3-TGAI.

After obtaining a schedule of a series of activities, a schedule development is carried out by conducting a CPM analysis. From this analysis it can be seen which activities are the critical path. Figure 2 is an example of the critical path obtained at the planning stage. Determination of the critical path is also carried out at later stages. Knowing that the critical path of each stage is an asset to focus the analysis on these activities There are 4 critical paths that are known from data processing:

1. A-B-E-F-G-H-I-J.

2. K-M-N-O-P-Q.

3. R-S-T.

\section{U-V-W-X}

After knowing the critical path of each stage, an analysis of the activity schedule on the critical path is carried out. By conducting FGD with the parties involved, it was found that some activities that fall into the critical path could be accelerated over time. These activities include:

1. Activities I.

2. Activities J.

3. Activity $\mathrm{O}$.

4. Activity S.

5. Activities U.

6. Activity Y.

\section{CONCLUSION}

Based on the results of the discussion and scheduling carried out in this study, it can be concluded that: (1) So far, the schedule implemented at P3-TGAI is still not effective to be implemented. This is proven by making a schedule based on the estimated time and resources that have been running for 347 days; (2) After analyzing CPM and FGD with parties related to P3-TGAI, it can be seen that several activities on the critical path can be accelerated to achieve the optimal schedule. The schedule that previously reached 347 days can be shortened to 312 days.

\section{REFERENCES}

[1] Project Management Institute, Inc., 2013. A Guide to The Project Management Body of Knowledge (PMBOK Guide). 5th ed. Pennsylvania: PMI.

[2] Firmansyah, A. \& Aryanny, E., 2020. Penjadwalan Proyek Pembuatan Lambung Kapal Cepat Rudal Dengan Critical Path Method Di Divisi Kapal Perang PT XYZ. urnal Manajemen Industri dan Teknologi , I(1), pp. 1-11.

[3] Herianto, Mahdi, I. \& Asif, M., 2020. Analisa Penerapan Metode Pert Dan Crashing Pada Perencanaan Jadwal Proyek (Studi Kasus : Proyek Pembangunan Gedung Sarana Diklat BKPSDM Kabupaten Ciamis). Akselerasi: Jurnal Ilmiah Teknik Sipil, 1(2).

[4] Nalhadi, A. \& Suntana, N., 2017. Analisa Infrastruktur Desa SukaciBaros Dengan Metode Critical Path Method (CPM). Jurnal Sistem dan Manajemen Industri Vol 1 No 1, pp. 35-42.

[5] Priyanto, E., Ervadius, B. \& Mochamad Anang, W., 2019. Percepatan Waktu Dan Biaya Terhadap Perencanaan Proyek Fabrikasi Steam Turbin Building Blok 2 Muara Tawar Dengan Metode CPM. Jurnal Keilmuan dan Terapan Teknik, VIII(2), pp. 24-33.

[6] Rosanti, N., Setiawan, E. \& Ayuningtyas, . A., 2016. Penggunaan Metode Jalur Kritis Pada Manajemen Proyek (Studi Kasus: PT. Trend Communications International). Jurnal Teknologi Universitas Muhammadiyah Jakarta, VIII(1).

[7] Taurusyanti, D. \& Lesmana, M. F., 2015. Optimalisasi Penjadwalan Proyek Jembatana Girder Guna Mencapai Efektifitas Penyelesaian dengan Metode PERT dan CPM pada PT. Buana Masa Metalindo. Jurnal Ilmiah Manajemen Fakultas Ekonomi, I(1). 